\title{
PRODUCTION OF CORROSION INHIBITORS FOR OIL REFINING EQUIPMENT USING NATURAL COMPONENTS
}

\author{
Petro Topilnytskyy ${ }^{1, *}$, Victoria Romanchuk ${ }^{1}$, Tetiana Yarmola ${ }^{1}$
}

https://doi.org/10.23939/chcht12.03.400

\begin{abstract}
It is proposed to use plant and animal raw materials to produce corrosion inhibitors of oil refining equipment. The corrosion inhibitors based on vegetable oil and animal fat with di- and triethanolamine have been synthesized, nitrogen-containing corrosion inhibitors have been obtained, their physical and chemical parameters have been determined. By using the gravimetric method the protective effect of the received inhibitors was determined on St20 steel in a two-phase corrosive environment simulating the preliminary preparation conditions of oil at electro-salting and dehydration plants. It was shown that inhibitors on the basis of plant and animal raw materials, obtained under certain synthesis conditions, are able to protect the metal surface of oil refining equipment.
\end{abstract}

Keywords: corrosion, oil refining equipment, corrosion inhibitors, protective effect.

\section{Introduction}

In most cases, water is a constant component that comes along with oil from the well. Stratal water of oil wells, which is one of the main aggressive environments, promotes the development of intensive electrochemical corrosion of equipment. The presence of chlorides in water is a major factor causing equipment corrosion. Salts which are dissolved in the stratal water behave differently. Sodium and potassium chlorides practically do not hydrolyze, so they cause only electrochemical corrosion of the equipment. Magnesium chloride is the most dangerous because it hydrolyzes by $90 \%$ even at low temperatures. At oil heating to $393 \mathrm{~K}$ and higher temperatures in the presence of even traces of water there is an intense hydrolysis with the formation of chloride acid, which causes chemical corrosion of the equipment. On the other hand, during distillation of oil with sulfur compounds a hydrogen sulfide is formed, which

\footnotetext{
${ }^{1}$ Lviv Polytechnic National University

12, Bandery St., 79013 Lviv, Ukraine

topoil@lp.edu.ua

(c) Topilnytsyy P., Romanchuk V., Yarmola T., 2018
}

(especially in combination with chloride acid) causes the strongest corrosion. In the presence of water or at elevated temperatures hydrogen sulfide reacts with metal apparatus and forms iron sulfide. Protective film with FeS covers the metal surface, partially protecting it from corrosion, but in the presence of chloric acid, the protective film is destroyed due to the reaction of sulfide with acid. The resulting iron chloride passes into an aqueous solution, and released hydrogen sulfide reacts again with iron [1-4].

Thus, the pretreatment of oil must necessarily include processes of dehydration and desalination.

A qualitative way of destroying water-oil emulsions is a method based on electric field action [2]. It is carried out in electrodehydrators. Under the action of an alternating voltage, the movement of charged droplets of water occurs, which leads to their collision, agglomeration and deposition. Water accumulates in the lower part of the electrodehydrator and then moves to a special tank. Since the separated water contains a lot of salts and some hydrocarbon phase, this leads to an intense corrosion of the drainage pipelines and the water tanks.

It is well known that the most simple and relatively inexpensive method of protecting equipment is the use of inhibitors. A corrosion inhibitor, introduced into an aggressive environment, inhibits the corrosive destruction of metals. There are number of requirements for inhibitors: to provide a certain maximum protective action at low concentration; be technological (do not derange the normal technological mode of the plants, do not impair the quality of products and the catalysts action); be economical; be resistant to redox processes; be non-toxic and environmentally friendly.

At present, a large number of corrosion inhibitors are known for the metals protection. Most of them are organic compounds of various classes that contain heteroatoms: nitrogen, sulfur, oxygen, phosphorus, silicon [5-7]. The use of natural materials as alternative corrosion inhibitors, plant raw materials in particular, is a promising direction in this area. The advantages of these materials: they are non-toxic, biodegradable, renewable, relatively cheap, easily available and environmentally friendly. These natural materials contain phytochemicals (tannins, alkaloids, amino acids, flavonoids, 
saponin phenols, etc.) and functional groups such as $-\mathrm{NH}_{2}$, $-\mathrm{NR}_{2},-\mathrm{SR}$ and $-\mathrm{COOH}$, which provide adsorption of these substances on the metal surface.

A number of researches have been carried out regarding the use of natural products as corrosion inhibitors. Chigirinets et al. [8] proposed to use rape-cake extract, macerating in the 2-propanol alcohol. Alarmal Mangai et al. [9] showed the corrosion inhibition effect of alkaloid extract part of the plant Trichodesma indicum (Linn) R. Br. of Boraginaceae family. Extracts of Funtumia elastica, Piper guineense, Telfairia occidentalis, Azadirachta indica, Hibiscus sabdariffa, Ocimum gratissimum, Chamaemelum mixtum, Nigella sativa, Wrightia tinctoria, Ipomoea triloba, Lupinousalbus, Tridax procumbens and Chromolaena odorata [10-20] have been investigated for their inhibition effects on various metals. Animal fats can also be used as corrosion inhibitors [21].

The purpose of this work is to obtain nitrogencontaining substances from plant and animal raw materials and to investigate their inhibition effects in highly corrosive media.

\section{Experimental}

According to literature data [6], the corrosion inhibitors based on unsaturated acids exhibit a greater protective effect compared with those on saturated acids. Therefore, we used vegetable oils with the highest content of unsaturated acids: corn, soya and sunflower oils (Table 1). In soya oil the total content of unsaturated acids is $77.0 \%$, in sunflower $-91.5 \%$, in corn $-80.5 \%$. For comparison we used coconut oil, in which the content of unsaturated acids is quite small $(8 \%)$, but there is a sufficient content of saturated lauric acid $(48 \%)$. All these products are the mixtures of glycerol and the corresponding acids. To extend the range of raw materials and to compare the protective properties we also studied beef fat, because it contains $51.0 \%$ of unsaturated acids.

To obtain inhibitors, the fat or oil was loaded into a three-necked flask and di- or triethanolamine was added. The amount of di- or triethanolamine was calculated based on the ratio of components in the reaction and their molecular weight. The flask was heated to $393,403,413$ or $423 \mathrm{~K}$ and stirred for 3-5 h.

Amines of fatty acids are formed due to the reaction of beef fatty acids with diethanolamine. During reaction of vegetable oils with diethanolamine we received amines of fatty acids and glycerin, which is a part of the corrosion inhibitor. When the acids interact with triethanolamine, esters are formed. The density, refractive index and protective corrosion effect were determined in the resulting products.

Investigation of inhibition effect was carried out by a gravimetric method, developed by Gajek et al. [5]. Quantitative evaluation of the inhibitor effect (at a certain concentration) on the corrosion rate is characterized by a protective effect $Z$ :

$$
Z=\frac{V_{0}-V}{V_{0}} \cdot 100 \%
$$

where $V_{0}$ - corrosion rate of a metal in a corrosive medium, $\mathrm{g} /\left(\mathrm{m}^{2} \cdot \mathrm{h}\right) ; V$ - corrosion rate of a metal after introducing the inhibitor, $\mathrm{g} /\left(\mathrm{m}^{2} \cdot \mathrm{h}\right)$.

Corrosion rate $V$ is calculated according to Eq. (2):

$$
V=\frac{\Delta m}{S \cdot \tau}
$$

where $\Delta m$ - reduction of the metal plate weight due to corrosion, $\mathrm{g} ; \tau$ - the experiment time, $\mathrm{h} ; S$ - surface area of the test plate, $\mathrm{m}^{2}$.

A jet fuel-water system with a ratio of $1: 2(\mathrm{v} / \mathrm{v})$ was used as a simulated corrosive medium. The water phase with density of $1.12 \mathrm{~g} / \mathrm{cm}^{3}$ contains magnesium chloride, calcium and sodium [5]. This system simulates stratal water of oil producing enterprises or corrosive medium formed in water tanks after electrodehydrators. The temperature under which the corrosion was determined in all cases was $333 \mathrm{~K}$, the experiment time $2 \mathrm{~h}$, the inhibitors consumption $0.6 \mathrm{ml}$ per $300 \mathrm{ml}$ of corrosive medium.

Table 1

Composition of oils and beef fat [22]

\begin{tabular}{|l|c|c|c|c|c|c|c|c|}
\hline \multicolumn{1}{|c|}{ Acids } & Formula & $\begin{array}{c}\text { Molecular } \\
\text { weight }\end{array}$ & $\begin{array}{c}\text { Melting } \\
\text { point, } \mathrm{K}\end{array}$ & $\begin{array}{c}\text { Coconut } \\
\text { oil, \% }\end{array}$ & $\begin{array}{c}\text { Corn } \\
\text { oil, \% }\end{array}$ & $\begin{array}{c}\text { Soya } \\
\text { oil }\end{array}$ & $\begin{array}{c}\text { Sunflower } \\
\text { oil, } \%\end{array}$ & $\begin{array}{c}\text { Beef } \\
\text { fat, } \%\end{array}$ \\
\hline Lauric & $\mathrm{C}_{12} \mathrm{H}_{24} \mathrm{O}_{2}$ & 200 & 319.6 & 48 & - & - & - & - \\
\hline Myristic & $\mathrm{C}_{14} \mathrm{H}_{28} \mathrm{O}_{2}$ & 228 & 331.0 & 17 & - & - & - & - \\
\hline Palmitic & $\mathrm{C}_{16} \mathrm{H}_{32} \mathrm{O}_{2}$ & 256 & 335.9 & 9 & $9-19$ & - & - & 32.5 \\
\hline Stearic & $\mathrm{C}_{18} \mathrm{H}_{36} \mathrm{O}_{2}$ & 284 & 342.9 & 2 & $1-3$ & $3-5$ & $3-6$ & 14.5 \\
\hline Oleic & $\mathrm{C}_{18} \mathrm{H}_{34} \mathrm{O}_{2}$ & 282 & 286.2 & 7 & $26-40$ & $22-31$ & $14-35$ & 48.3 \\
\hline Erucic & $\mathrm{C}_{22} \mathrm{H}_{42} \mathrm{O}_{2}$ & 333 & 306.5 & - & - & - & - & - \\
\hline Linoleic & $\mathrm{C}_{18} \mathrm{H}_{32} \mathrm{O}_{2}$ & 280 & - & 1 & $40-55$ & $43-58$ & $59-75$ & 2.7 \\
\hline Linolenic & $\mathrm{C}_{18} \mathrm{H}_{30} \mathrm{O}_{2}$ & 278 & - & - & 1 & $6-11$ & - & - \\
\hline $\begin{array}{l}\text { Average amount of } \\
\text { unsaturated acids }\end{array}$ & - & - & - & 8.0 & 80.5 & 77.0 & 91.5 & 51.0 \\
\hline
\end{tabular}


Composition of the metal (wt \%) used for investigations

\begin{tabular}{|c|c|c|c|c|c|c|c|c|c|}
\hline $\mathrm{C}$ & $\mathrm{Mn}$ & $\mathrm{Si}$ & $\mathrm{Cr}$ & $\mathrm{Ni}$ & $\mathrm{Cu}$ & $\mathrm{P}$ & $\mathrm{S}$ & As & $\mathrm{Al}$ \\
\hline $0.17-0.24$ & $0.35-0.65$ & $0.17-0.37$ & $\leq 0.25$ & $\leq 0.3$ & $\leq 0.3$ & $\leq 0.035$ & $\leq 0.04$ & $\leq 0.08$ & - \\
\hline
\end{tabular}

The study of the inhibition effect by the gravimetric method was carried out using a metal plate made of steel St20. The composition of the metal is given in Table 2.

\section{Results and Discussion}

The synthesis conditions and obtained results are presented in Tables 3 and 4.

One can see from Table 3 that the density and refractive index of the resulting products change within narrow ranges. The protective effect $Z$ varies depending on the product used (fat or oils), the amount of added diethanolamine, synthesis time and temperature. Thus, when using diethanolamine in the amount of $25 \%$ for $3 \mathrm{~h}$ at different synthesis temperatures, the protective effect of the samples 1-3 was insignificant $26-49 \%$. Moreover, the product obtained at the lowest temperature (sample 1) had the smallest effect. Sample 4, obtained under similar conditions (temperature $403 \mathrm{~K}$, time $3 \mathrm{~h}$ ), but with a higher content of diethanolamine $(35 \%)$, showed a protective effect, similar to the previous products $(46.74 \%)$. And sample 5 with $15 \%$ diethanolamine did not protect the metal surface at all.

With the increase in the synthesis time to 4 or $5 \mathrm{~h}$ (samples 6 and 7) we observed the considerable increase in the protective effect (74.66 and $64.88 \%$, respectively). So, when using inhibitors based on beef fat with diethanolamine, the protective effect of the resulting products passes through the maximum at $403 \mathrm{~K}$, further increase in temperature leads to a slight decrease in the protective effect. The increase in the synthesis time influences the protective effect of substances more significantly, but also passes through the maximum. The optimum time is $4 \mathrm{~h}$. Increasing or decreasing the ratio of components from a stoichiometrically calculated one leads to the decrease in the efficiency. The excess acid or amine content does not have a positive effect.

If we analyze the efficiency of amines derived from oils, we observe the dependence of the product's efficiency on the total content of unsaturated acids in the virgin oil. The highest protective effect has the product based on sunflower oil and the smallest - based on coconut oil.

Table 4 shows the synthesis of fat and oils with triethanolamine, the indices and protective effect of the resulting inhibitors.
When producing esters based on beef fatty acids and triethanolamine, the optimal synthesis temperature is $393-403 \mathrm{~K}$; the efficiency of esters is significantly higher than that of amines. In the case of the use of triethanolamine, the protective effects of all products increase. At the same time, the greatest protective effect $(80 \%)$ is observed for the inhibitor, obtained from refined sunflower oil at $423 \mathrm{~K}$ for $4 \mathrm{~h}$. The inhibitor obtained from beef fat at $393 \mathrm{~K}$ for $3 \mathrm{~h}$ also shows a high protective effect $(79 \%)$. The product from crude sunflower oil slightly protects the metal surface; the highest protective effect was $75 \%$ for the product obtained at $413 \mathrm{~K}$ for $4 \mathrm{~h}$. The same synthesis conditions were found to be the best for the inhibitors based on corn oil. For the inhibitors based on coconut oil the synthesis temperature is lower $(403 \mathrm{~K})$ and time $4 \mathrm{~h}$. The protective effects of esters derived from different oils have different dependence on the synthesis temperature. For refined sunflower oil, the protective effect increases significantly with the increase in temperature to $423 \mathrm{~K}$, for crude sunflower oil the maximum efficiency is achieved at $403-413 \mathrm{~K}$, for corn oil - at $403 \mathrm{~K}$. The same as for the inhibitors obtained from oils and diethanolamine, esters show greater or less effect at different content of unsaturated acids in triglycerides of oil. Different effect of the product obtained from refined and crude oils can be explained by different content of saturated and unsaturated acids in the oils, as well as by the presence of impurities in crude oil which become an ineffective ballast. At the same time, despite the lowest content of unsaturated acids in coconut oil (7\%), this inhibitor shows a fairly high protective effect $-70 \%$. The highest protective effect $(80 \%)$ was shown by the inhibitor synthesized from refined sunflower oil at $423 \mathrm{~K}$ for $4 \mathrm{~h}$.

When comparing the protective effect of the resulting inhibitors, it can be argued that all products (amines and esters) derived from oils and animal fat exhibit protective properties.

As it is known, the protective effect of inhibitors is explained by the "three-layer mechanism" [23]. The lower part of the three-layer film connects the molecule polar end and the metal surface. The protective effect depends on the strength of this connection. The medium part of the film is the nonpolar end of the molecule. Its influence on the protective effect is determined by the degree of wetting or screening of the surface, which can form these parts of the molecules. The upper layer of the film is a hydrophobic layer of hydrocarbons. This layer is an additional protective film that covers the main film of the 
inhibitor and creates a barrier for the diffusion of $\mathrm{Fe}^{++}$ions from the metal surface, as well as the diffusion of corrosive agents or water to the metal surface.

Obviously, the part of the molecules can be adsorbed due to nitrogen atoms of the amino group, and another part - due to the specific interaction of the polar $\mathrm{OH}$ group with the metal surface. This leads to a reduction in the repulsion forces between the inhibitor molecules and contributes to the formation of a more dense protective film.

Table 3

Synthesis conditions and indices of the inhibitors from mixtures of vegetable oil or beef fat and diethanolamine

\begin{tabular}{|c|c|c|c|c|c|c|}
\hline Sample & Temperature, $\mathrm{K}$ & Time, $\mathrm{h}$ & Components ratio. w/w & $n_{D}{ }^{20}$ & $\rho_{4}{ }^{20}$ & $Z, \%$ \\
\hline \multicolumn{7}{|c|}{ Beef fat/diethanolamine } \\
\hline 1 & 393 & 3 & $75 / 25$ & 1.4867 & 0.9646 & 26.09 \\
\hline 2 & 403 & 3 & $75 / 25$ & 1.4866 & 0.9859 & 48.91 \\
\hline 3 & 413 & 3 & $75 / 25$ & 1.4866 & 0.9741 & 47.83 \\
\hline 4 & 403 & 3 & $65 / 35$ & 1.4865 & 0.9914 & 46.74 \\
\hline 5 & 403 & 3 & $85 / 15$ & 1.4865 & 0.9570 & -22.39 \\
\hline 6 & 403 & 4 & $75 / 25$ & 1.4652 & 0.9771 & 74.66 \\
\hline 7 & 403 & 5 & $75 / 25$ & 1.4663 & 0.9781 & 64.88 \\
\hline \multicolumn{7}{|c|}{ Vegetable oil/diethanolamine } \\
\hline 8 & 403 & 4 & (sunflower) $78 / 22$ & - & - & 80.34 \\
\hline 9 & 403 & 4 & (soya) $78 / 22$ & - & - & 54.26 \\
\hline 10 & 403 & 4 & (coconut) 74/26 & - & - & 43.62 \\
\hline
\end{tabular}

Table 4

\section{Synthesis conditions and indices of the inhibitors from mixtures of vegetable oil or beef fat and} triethanolamine

\begin{tabular}{|c|c|c|c|}
\hline Temperature, $\mathrm{K}$ & $n_{D}{ }^{20}$ & $\rho_{4}^{20}$ & $Z, \%$ \\
\hline \multicolumn{4}{|c|}{ Beef fat/triethanolamine $64.5 / 35.5(\mathrm{w} / \mathrm{w})$, time $3 \mathrm{~h}$} \\
\hline 393 & 1.4813 & 1.0230 & 79.52 \\
\hline 403 & 1.4804 & 1.0130 & 77.92 \\
\hline 413 & 1.4817 & 0.9839 & 76.38 \\
\hline 423 & 1.4764 & 0.9965 & 67.69 \\
\hline \multicolumn{4}{|c|}{ Refined sunflower oil/triethanolamine 69.3/30.7 (w/w), time $4 \mathrm{~h}$} \\
\hline 393 & 1.4672 & 0.9684 & 9.46 \\
\hline 403 & 1.4822 & 0.9757 & 37.77 \\
\hline 413 & 1.4804 & 0.9839 & 40.92 \\
\hline 423 & 1.4789 & 0.9758 & 80.31 \\
\hline \multicolumn{4}{|c|}{ Crude sunflower oil/triethanolamine $69.3 / 30.7(\mathrm{w} / \mathrm{w})$, time $4 \mathrm{~h}$} \\
\hline 393 & 1.4785 & 0.9192 & 4.69 \\
\hline 403 & 1.4786 & 0.9704 & 69.31 \\
\hline 413 & 1.4772 & 0.9789 & 75.62 \\
\hline 423 & 1.4834 & 0.9844 & 21.23 \\
\hline \multicolumn{4}{|c|}{ Corn oil/triethanolamine $65.3 / 34.7(\mathrm{w} / \mathrm{w})$, time $4 \mathrm{~h}$} \\
\hline 393 & 1.4792 & 0.9754 & 11.77 \\
\hline 403 & 1.4825 & 0.9814 & 68.46 \\
\hline 413 & 1.4749 & 0.9829 & 49.21 \\
\hline 423 & 1.4814 & 0.9854 & 33.08 \\
\hline \multicolumn{4}{|c|}{ Coconut oil/triethanolamine $67.0 / 33.0(\mathrm{w} / \mathrm{w})$, time $4 \mathrm{~h}$} \\
\hline 393 & 1.4830 & 0.9400 & 45.69 \\
\hline 403 & 1.4815 & 0.9580 & 70.08 \\
\hline 413 & 1.4795 & 0.9750 & 47.85 \\
\hline 423 & 1.4818 & 0.9800 & 66.15 \\
\hline
\end{tabular}


Organic compounds with long hydrocarbon chains have both polar and nonpolar ends. In our case, this applies to saturated and unsaturated acids that form the basis of inhibitors. In unsaturated acids the inhibitory properties are provided by the presence of several adsorption centers. The interaction involves the polar parts of the molecule (the nitrogen atom and esteric group) and hydrophobic part (alkyl radicals with different lengths of the hydrocarbon chain, which is further adsorbed on the metal surface due to unsaturated bonds). The hydrocarbon radicals directed toward the solution repel the active particles of the medium from the steel surface. Together with hydrophobicity, the shielding of large areas of the surface is also provided. This influence has an extreme character. With the increase in the aliphatic radical length the hydrophobicity increases linearly, and surface activity decreases. In saturated acids, the nitrogen atom and the ether group also act as adsorption centers, but the hydrophobic part, which is the alkyl radical, does not enter the addition reaction due to a saturated coupling and does not form an additional adsorption layer on the metal surface. The protective effect of nitrogen-containing compounds is also affected by the length of hydrocarbon radicals with hydrophobic properties. The $\mathrm{C}_{16}-\mathrm{C}_{18}$ hydrocarbon radical was found to be the best. In addition, in our case, the effectiveness of inhibitors depended on the synthesis conditions (time and temperature) and, accordingly, the reaction completeness.

\section{Conclusions}

So, we determined the most optimum conditions for obtaining highly effective inhibitors: synthesis time $4 \mathrm{~h}$, and the temperature $403 \mathrm{~K}$ in the case of diethanolamine, and $423 \mathrm{~K}$ in the case of triethanolamine. The greatest protective effect was found for the inhibitor based on refined sunflower oil, and both di- and triethanolamine. The total amount of acids in this oil was $91.5 \%$, which confirms the greater efficiency of this product compared to those that have saturated acids. Thus, amines and esters of sunflower oil acids exhibit an equally high protective effect even in highly aggressive corrosive media.

\section{References}

[1] Topilnytskyy P., Grynyshyn O., Machynskyy O.: Technologia Pervynnoi Pererobky Nafty i Gazu. Vyd-vo Lviv Polytechnic, Lviv 2014.

[2] Topilnytsky P.: Chem. Chem. Technol., 2007, 1, 45.

[3] Shalaby H., Ravindranath K., Tanoli N., Al-Wakaa B.: Case Stud. Eng. Failure Anal., 2017, 9(C), 1. https://doi.org/10.1016/j.csefa.2017.04.004

[4] Ormellese M.: Corrosion in Oil and Chemical Industry [in:] Wandelt K. (Ed.), Encyclopedia of Interfacial Chemistry: Surface Science and Electrochemistry, Elsevier 2018, 145-154.
[5] Gajek A., Zakroczymski T., Topilnytsky P., Romanchuk V.: Chem. Chem. Technol., 2012, 6, 209.

[6] Romanchuk V., Topilnytsky P.: Chem. Chem. Technol., 2010, 4, 231.

[7] Goyal M., Kumar S., Bahadur I. et al.: J. Mol. Liq., 2018, 256, 565. https://doi.org/10.1016/j.molliq.2018.02.045

[8] Chygyrynets' E., Vorobyova V.: Chem. Chem. Technol., 2014, 8, 235.

[9] Mangai A., Ravi S.: J. Chem.,2013, 2013, 4.

http://dx.doi.org/10.1155/2013/527286

[10] Raghavendra N., Ishwara Bhat J.: Res. Chem. Intermed., 2016, 42, 6351. https://doi.org/10.1007/s11164-016-2467-1

[11] Adindu C. et al.: Int. Lett. Chem., Phys., Astron., 2016, 68, 24. https://doi.org/10.18052/www.scipress.com/ILCPA.68.24

[12] Njoku D., Ukaga I., Ikenna O. et al.: J. Mol. Liq., 2016, 219, 417. https://doi.org/10.1016/j.molliq.2016.03.049

[13] Okafor P., Ebenso E.: Pigm. Resin Technol., 2007, 36, 134. https://doi.org/10.1108/03699420710748992

[14] Eddy N., Ebenso E.: Pigm. Resin Technol., 2010, 39, 77. https://doi.org/10.1108/03699421011028653

[15] Patel N., Jauhari S., Mehta G.: e-J. Chem., 2009, 6, S189.

https://doi.org/10.1155/2009/413421

[16] Oguzie E., Iheabunike Z., Oguzie K. et al.: J. Dispers. Sci. Technol., 2013, 34, 516.

https://doi.org/10.1080/01932691.2012.682008

[17] Oguzie E., Ogukwe C., Ogbulie J. et al.: J. Mater. Sci., 2012,

47, 3592. https://doi.org/10.1007/s10853-011-6205-1

[18] Oguzie E.: Corros. Sci., 2008, 50, 2993.

https://doi.org/10.1016/j.corsci.2008.08.004

[19] Oyedeji O., Adeniyi B., Ajayi O., Konig W.: Phytother. Res., 2005, 19, 362. https://doi.org/10.1002/ptr.1679

[20] Aribo S., Olusegun S., Ibhadiyi L. et al.: J. Assoc. Arab Univ. Basic Appl. Sci., 2017, 24, 34.

https://doi.org/10.1016/j.jaubas.2016.08.001

[21] Pujar M., Miller A., Proroka M. et al.: J. Mater. Sci. Lett., 2000, 19, 1797. https://doi.org/10.1023/A:1006782020757

[22] Evdokimov A., Fuks I., Shabalina T., Bagdasarov L.: Smazochnye Materialy. Heft i gaz, Moskva 2000.

[23] Bregman J.: Corrosion Inhibitors. Macmillan, New York 1963.

Received: December 06, 2017 / Revised: December 15, 2017 /

Accepted: January 22, 2018

\section{ЗАСТОСУВАННЯ НАТУРАЛЬНИХ КОМПОНЕНТІВ ДЛЯ ОДЕРЖАННЯ ІНГІБІТОРІВ КОРОЗІЇ НАФТОПЕРЕРОБНОГО ОБЛАДНАННЯ}

Анотація. Запропоновано застосування рослинної та тваринної сировини для одержання інгібіторів корозії нафтопереробного обладнання. Проведено синтез інгібіторів корозії на основі олій та тваринного жсиу з ди- та триетаноламіном, одержано нітрогенвмісні інгібітори корозії, визначено їх фізико-хімічні показники. Гравіметричним методом визначено ступінь захисту одержаних інгібіторів на сталі Ст20 в двофазному корозійному середовищі, щзо імітує середовище установок електрознесолення та зневоднення за умов підготовки нафти до перероблення. Показано, щзо інгібітори на основі рослинної та тваринної сировини, одержані за певних умов синтезу, здатні захищати металеву поверхню нафтопереробного обладнання.

Ключові слова: корозія нафтопереробного обладнання, інгібітори корозї, захисний ефект. 